\title{
Sustainable Community Development ${ }^{1}$
}

\author{
M.E. Swisher, Sandra Rezola and James Sterns ${ }^{2}$
}

\section{Overview}

This document explores the idea of sustainable community development and what this type of development can do to improve the quality of life within communities. This document examines what sustainable development entails and provides examples of the threats to quality of life that traditional approaches to development can generate. This document outlines six steps to a more sustainable approach to community development.

\section{Sustainable Community Development}

Sustainable Communities Are:
Environmentally Sound: Decision-making focuses on reducing the impacts of population growth and
development on natural resources and the environment.
Economically Productive: Community members make local capital investments that will sustain local
human and natural resources and yield adequate financial returns to those investments.
Socially Just: Equitable access to resources and decision-making processes foster the distribution of
foods and benefits across all sectors to the community.

Imagine a community where the air and water are clean, water supplies fully meet demand and everyone enjoys access to locally supplied safe and healthy foods, wildlife flourishes and the landscape is pleasing to the eye. Within this community, full participation and a spirit of cooperation pervade decision-making. People have an impact over their community's future. The community revitalizes the city center, reduces sprawl and promotes regional identity and pride. Public transportation effectively reduces congestion and pollution from cars, reduces transportation costs, and improves access to jobs and services. The community has established a living wage standard for all employees. A strong emphasis on education and training for all promotes an improved quality of life today and fosters future opportunities for the community's youth.

Far from being simply an exercise in imagination, communities across the nation are realizing similar visions of sustainable development for their communities. For instance, Sarasota, Florida began its 20/20 Foresight Sustainable Development Visioning Process in the 1990s in a response to urban

1. This document is FCS7213-Eng, one of a series of the Department of Family, Youth and Community Sciences, Florida Cooperative Extension Service, IFAS, University of Florida, Gainesville FL 32611: First published: September 2003. Reviewed by Jerry Culen, Ph.D., associate professor and Amy Simmone, Ph.D., assistant professor, Department of Family, Youth and Community Sciences, and Burl Long, Ph.D., professor, Department of Food and Resource Economics, University of Florida, Gainesville, Florida, 32611. Please visit the EDIS Web site at http://edis.ifas.ufl.edu

2. M.E. Swisher, Ph.D., associate professor, Department of Family, Youth and Community Sciences, Sandra Rezola, M.S., Institute of Food and Agricultural Sciences, and James Sterns, Ph.D., assistant professor, Department of Food and Resource Economics, University of Florida, Gainesville FL 32611. 
growth and sprawl, environmental deterioration, and traffic and water problems. Civic, public, and private partnerships formed to establish sustainable development goals. Since 1990, Sarasota has held three conferences on community sustainability, partly to guide development in Sarasota's downtown area through the year 2040. A public-private partnership of the Sarasota County Cooperative Extension Service and the Florida House Foundation created the Florida House Learning Center to promote sustainable development in residential settings. To reduce pesticide use and exposure, the county implemented an integrated pest management program for all county facilities in 1991. The county has also established Florida's most comprehensive recycling program and has worked to restore the Sarasota Bay's health with assistance from Mote Marine Laboratory. Other efforts of Sarasota's sustainability initiative have taken the form of centers, foundations, academic programs, and programs for land acquisition, economic development, resource conservation and environmental protection.

Other communities throughout the nation are putting their visions into action, too. Sustainable community development may be the initiative for Florida not in some distant future, but tomorrow.

\section{Trends Threatening Florida's Communities}

Florida's population has dramatically expanded from around 2.8 million in 1950 to 15.6 million in 2000. The Census Bureau says that immigration, high birth rates and domestic migration will drive Florida's population to 20.7 million by 2025. Between 1970 and 1990 Florida's urban areas sprawled over one million acres of formerly rural land - natural habitats, farmland, and scenic open spaces often converted to strip malls, housing developments, and low-density commercial development (Kolankiewicz and Beck, 2000). Uncontrolled growth has created environmental, social, and economic problems that threaten to destroy the very attractions that made many move to the state and that both native Floridian and newcomer alike value highly.

Water resources provide a good example. Florida has the highest domestic per capita water use in the country and ranks second nationally in water use for mining, fourth in use for public supply, and eleventh in use for irrigation. Due mostly to population growth, projections show that water supplies will not meet projected demands by 2020. Restrictions on water use are the result of competition between communities and between urban residents and farmers. In addition, urban storm water, agricultural runoff, industrial and municipal point source pollution, and construction contribute to water pollution across the state. Mercury contamination in fish is but one example of the state's pressing water pollution problems.

\section{A Focus on the Community}

Florida, like most of the nation, needs a plan of action to better address environmental, social and economic development. Seen at the state level, Florida's problem may appear too great and the solutions too elusive for effective action. But problems like urban sprawl, environmental degradation, and social injustice become personal and real in our communities where we live and work. We face these problems at the community level and we can solve them at the community level. For example, the UN World Commission on the Environment and Development defined sustainable development as development that "meets the needs of the present without compromising the ability of future generations to meet their own needs." At the community level these abstract goals can be translated into concrete, effective action.

Each community must develop its own vision and plan of action. There is no single definition of sustainable community development because every community has its own unique characteristics and 
challenges. Yet sustainable communities share common themes and concerns: economic security, environmental protection, social justice, and a commitment to the welfare of future generations.

Sustainable communities recognize that their economic and social structures and the health of the local environment are intertwined. They understand that programs and policies that foster only one aspect of development, be it economic growth, social gain, or environmental protection, to the exclusion of the other two aspects will not promote sustained progress for the community. For instance, consumers take into account how local farms protect the environment and contribute to the local economy when they make their food purchasing decisions. Natural resource managers consider the capacity of the community in terms of not just natural capital, but human, social, and physical capital capacity to maintain the population when they make their decisions. Leaders look beyond short-term outcomes and conflicts to identify and build upon the long-term shared interests among their members.

\section{Taking Action}

In order to implement a strategy for sustainable development, members of the community must believe that they have the capacity to resolve their own problems and shape their own future. A spider's web looks fragile, but it can withstand extraordinary force with little damage. Strengthening the community's capacity is like weaving a web that creates a social network throughout the community, providing support for all and extending and strengthening cooperation and collaboration among people, institutions, organizations, and businesses. Even if it starts small, the network expands and incorporates more and more of the stakeholders. The network increases community cohesion and resilience through innovative partnerships, increased collaboration, and a shared vision of the future.

Sustainable community initiatives, like the one in Sarasota, deal with global issues at the local level. There are many paths to sustainable development, as many as there are communities. The following steps may help your community build and implement a sustainable vision of its own. Click on the links to get to the other documents in this series.

1. Get stakeholder agreement on implementing a sustainability program.

2. Conduct a community assessment.

3. Create a community vision and develop a roadmap for reaching that vision.

4. Develop sustainability indicators to measure progress.

5. Identify sources of help.

6. Carry out projects and monitor, evaluate, and make adjustments as needed.

\section{References}

Kolankiewicz, L. and Beck, R. 2000. Sprawl in Florida. SprawlCity. Retrieved from http://www.sprawlcity.org

Mishel, L., Bernstein, J. and Schmitt, J. 2000. The State of Working America 2000-01, Cornell University Press, Ithaca, NY, p.153.

U.S. Census Bureau. (2000). Profile of Selected Economic Characteristics: 2000. 